\title{
Letren abiadura Lehen Hezkuntzan: euskarazko batezbestekoak ikasmailaren eta generoaren arabera
}

\author{
IrUne Ibarra, Xabier EtXaGue eta JuAn EtXeberria \\ Hezkuntzarako Ikerkuntza eta Diagnosi Metodoen saila \\ eta Didaktika eta Eskola Antolakuntza saila \\ (Hezkuntza, Filosofia eta Antropologia Fakultatea, UPV/EHU)
}

\section{(Handwriting performance's speed in Basque in Primary education: average results by grade and gender)}

DOI: $10.1387 /$ gogoa. 17910

\begin{abstract}
Laburpena
Eskuz idazterakoan komunikazio eraginkorra lortu nahi bada, idazten denak, irakurgarria izateaz gain, abiadura on batekin idatzia egon behar du (Barnett, Henderson, Scheib \& Schulz, 2009). Urte askotan klasikoa izan da letren irakurgarritasuna ebaluatzea eta azkenaldian letraren abiadura ebaluatzen duten testak garatu dira, besteak beste, HST testa Australian (Wallen, Bonney \& Lennox, 1996), PAL-II testa Estatu Batuetan (Berninger, 2007) eta DASH testa Erresuma Batuan (Barnett, Henderson, Scheib \& Schulz, 2007). Letraren abiadura neurtzea sinplea da eta haren eraginak garrantzitsuak dira eskolatzean: zeregin asko dago idatziz egiteko, apunteak hartu behar dira eta denbora-mugetan erantzun behar da. Gainera, neurogarapeneko idazketaren ikuspuntuaren baitan eginiko ikerketetan, letraren abiadurak testu-sorkuntzaren kantitatea eta kalitatea baldintzatzen du 16 urtera arte (Berninger \& Swanson, 1994; Berninger \& Graham, 1998). Bestalde, jakina da idazten den letrajarioa haziz doala ikasmailaz ikasmaila, gutxienez DBHko 2. mailaraino eta, nazioartean ikusi denaren arabera, hazten doan letra kopuru horretan generodesberdintasunak daude: mutilen puntuazioak esanguratsuki baxuagoak dira.
\end{abstract}

Artikulu honetan, lehenik, letren irakurgarritasunaren eta abiaduraren konstruktuak azalduko dira; bigarrenik, letra-abiadurak identifikatzeak duen garrantziaz jardungo gara eta, azkenik, Euskal Autonomia Erkidegoko (EAE) 
Lehen Hezkuntzako haurren letren abiadura-batezbestekoak agertuko dira, ikasmailaren eta generoaren arabera.

Gako-hitzak: esku-idazketa, letraren abiadura, Lehen Hezkuntzako idazketa, genero-desberdintasunak idazketan.

\begin{abstract}
To achieve effective communication through handwriting, the writing needs to be readable and fluid (Barnett, Henderson, Scheib \& Schulz, 2009). For many years, it has been usual to evaluate the readability of handwriting and, lately, tests have been developed that evaluate fluency/speed of handwriting, among others, the HST test in Australia (Wallen, Bonney \& Lennox, 1996), the PALII test in the United States (Berninger, 2007) and the DASH test in the United Kingdom (Barnett, Henderson, Scheib \& Schulz, 2007). The measurement of the handwriting fluency is simple and its effects are important in schooling: there are many works that must be handwritten, it is necessary to take notes and children have to respond in a time frame. In addition, according to studies carried out from the neurodevelopmental view of writing, the handwriting fluency affects the quantity and quality of the generation of texts until the age of 16 (Berninger \& Swanson, 1994; Berninger \& Graham, 1998). On the other hand, it is known that the speed of letters increases course after course, at least until the secondary years; and as it has been proven at international level, there is a gender-gap at this point: boys' results are significantly worse. In this article, first we will define the constructs of legibility and fluency/speed of handwriting. Afterwards, we will underline the importance of identifying the handwriting fluency and finally we will show the handwriting fluency results obtained in The Basque Autonomous Community (EAE), according to course and gender.
\end{abstract}

Keywords: handwriting, writing speed, primary grades writing, writing gender-gap.

\title{
1. Letra ulergarriak egitea eta letra azkarrak egitea eskolatzean
}

Tradizionalki, eskuz idaztearen emaitza den letra, formaren ikuspuntutik aztertu da; hau da, letraren «alde figuratiboa» (Haranburu, Alonso-Arbiol, Balluerka \& Gorostiaga, 2008) deritzona aztertu da. Halaber, kalitatezko letra, letra irakurgarriaren sinonimoa izan da; hau da, letraren kalitatearen ebaluazioa letraren zehaztasunak, garbitasunak edo irakurgarritasunak eman izan du (Rosenblum, Weiss \& Parush, 2003; Levin, 2010). Hortaz, letrak eskuz egitea, irakurgarritasunaren ikuspuntutik ebaluatu da eta ikasleen konposizioetan letra, aurkezpen-kontutzat hartu izan da (Medwell \& Wray, 2008). Irakurgarritasuna konstruktu unitario bat ez den arren (Weintraub \& Graham, 
2000), oro har, letraren irakurgarritasuna ebaluatzeko bi eskala mota nagusi egon izan dira: eskala holistikoak eta eskala analitikoak. Rosenblum et al.-en (2003) arabera eskala holistikoetan idazketa-ereduak erabili dira konparazioak egiteko, hau da, eredu irakurgarrienetatik eredu irakurgaitzenetara arteko laginak erabili dira konparatu nahi den idatziaren erreferente izateko (adibidez 1etik 5erako puntuazioan). Aldiz, eskala analitikoetan, letraren elementu zehatzagoak erabili dira erakusle gisan, hala nola, letra-formakuntza, espaziamendua, lerroen horizontaltasuna, neurria, etab. Graham, Berninger, Weintraub \& Schaferen (1998) arabera, letren irakurgarritasunaren urtez urteko garapenari dagokionez, emaitza nahasiak daude; batzuen ustez, hobekuntzak urtero ematen dira, beste batzuentzako hobekuntzak soilik instrukzioa egon den unean egoten dira eta beste batzuen ustez ikasmailen artean ez dago desberdintasunik. Bestalde, Berninger, Mizokawa \& Braggen (1991) esanetan, eskolan letra irakurgaitzak ondorioak ditu: batetik, ikasleek beraiek uste dute idazle txarragoak direla; bestetik, irakasleek, idatzitako testuen kalitate-balorazio apalagoak egiten dituzte. Azkenik, garai desberdinetako idazketaren irakurgarritasuna ere aztertu da. Adibidez, Overvelde \& Hulstijnek (2011) orain dela 20 urteko eta gaur egungo Lehen Hezkuntzako 2. mailako haurren idazketaren laginak konparatu dituzte irakurgarritasunaren arabera eta kalitate eskasagoa aurkitu dute gaur egungo laginetan. Kalitatea gutxitze horren arrazoiak honako hauek izan daitezke, egileen arabera: eskuz idazten irakasteari denbora gutxiago eskaintzea edo esku-idazketaren irakaskuntzaren kalitatea eskasagoa izatea.

Letra eskuz egitea abiaduraren ikuspuntutik ere aztertu da. Letra azkarra, gehienetan, irakurgarritasun-eskalen barruan aztertu da, eta aniztasun handia egon da datuak jasotzeko erabili diren moduetan. Nagusiki minutuko idatzi edo kopiatu den letra edo hitz kopurua neurtu da, bai erritmo lasaian eta bai erritmo azkarrean (Rosenblum et al., 2003). Adibidetzat har ditzakegu Australian HST testa (Wallen et al., 1996), Estatu Batuetan PAL-II testa (Berninger, 2007) eta Barnett et al.-en (2007) DASH testa. Horiek guztiek ingelesez idatzitako testuen letra-abiadura normatiboak ematen dituzte, herrialdeen arabera. Letra kopurua handitu egiten dela ikusi da oro har, denborarekin, adinarekin eta/edo eskolatzearekin (Berninger \& Fuller, 1992; Graham et al., 1998; O'Mahony, Dempsey \& Killeen, 2008; Barnett et al. 2009; Mackenzie, Scull \& Munsie, 2013). Egile horiek ikusi dutenez, haurrek zenbat eta gehiago konposatzen duten, orduan eta ohikoago edo automatikoago bihurtzen da esku-idazketa, eta ondorioa letraren abiaduraren handitzea izaten da. Halere, letren abiaduraren handitzea ez dela lineala erakutsi dute ikertzaile hauetako batzuek, hala nola, Graham et al.-ek (1998) eta O'Mahony et al.-ek (2008). Egile horien arabera, abiaduraren handitze horretan garapeneko bizkorraldiak eta geldialdiak egongo lirateke. Honela, bizkorraldiak ikusi dituzte derrigorrezko Lehen Hezkuntzako lehen hiru ikasmailetan zehar eta baita derrigorrezko Lehen Hezkuntza bukatu eta Bigarren Hezkuntza hasterakoan ere. Geldialdiak, aldiz, Lehen Hezkuntzako 4. eta 
5. maila bitartean ikusi dituzte. Bestalde, ikasmailaz ikasmaila letren abiaduran handitzeak ikusi dituzten arren, egia da, baita ere, ikasmaila bakoitzean ikasle batetik bestera aldakortasun handiak egon ohi direla (Graham et al., 1998; O'Mahony et al., 2008; Mackenzie et al., 2013). Generoaren arabera desberdintasun esanguratsuak ikusi dira abiaduran eta kontuan hartu beharreko faktorea dela diote Rosenblum et al.-ek (2003). Ikerketa gehienetan, neskek mutilek baino esanguratsuki azkarrago idatzi dute Lehen Hezkuntzako ikasmaila guztietan edo batzuetan (Ziviani, 1984; Judd, Siders, Siders \& Atkins, 1986; Berninger \& Fuller, 1992; Graham et al., 1998). Aldiz, 11-12 urtetik aurrera mutilek esanguratsuki azkarrago idatzi dute (Ziviani \& WatsonWill, 1998).

\section{Zertarako identifikatu letra-abiadurak?}

Arrazoi anitz egon daitezke ikasleek nahitaezko eskolaldian zehar dituzten letra-abiadurak identifikatzeko. Batetik, EAE-ko datuak izan ez arren, Estatu Batuetako estatistiken arabera, eskolako klase bakoitzean eskuz idazten 15 minutu baino gehiago pasatzen zuten 14 urtekoek (National Center for Education Statistics, 2012). Bestetik, idatziz egiten diren zeregin horietako hainbatek denbora-mugak dituzte eta garrantzitsua da denbora-muga horietan erantzun ahal izatea (Amundson \& Weil, 1996). Gainera, abiadura txikiak zehaztuta egotea funtsezkoa da azterketei begira, izan ere, ikasleek ez badute gutxi gorabehera adinekoen abiadura, desabantailan egongo dira azterketetan eta azterketa horien emaitzek ikasleek benetan dituzten gaitasunak gutxiestera eraman ditzake irakasleak (O'Mahony et al., 2008). Erresuma Batuan, adibidez, azterketa ofizialetan, aukera-berdintasuna bermatzeko, Joint Council for Qualifications-ek (2015) baliabideak jartzen dizkiete idazketazailtasunak identifikatuta dituzten ikasleei; baliabide horiek eskriba bat, denbora gehigarria eta/edo ordenagailua erabiltzeko aukera izatea dira. Bestalde, irakasleen aurkezpenak jarraitzeko oharrak behar izaten dira eta abiadura bat behar izaten da zeregin hori ondo egiteko.

Aipatutako guztia gutxi balitz, aurkikuntza garrantzitsu bat egin da neurogarapeneko idazketaren ikuspuntutik: letrak abiaduraz idaztea edo eskuidazketaren jario ona izatea giltzarria izan da testu luzeak eta kalitatezkoak sortu ahal izateko; hau da, letrak bizkor egin dituenak hitz kopuru handiak eta testu koherenteak idazten ditu ingelesez (Berninger \& Swanson, 1994; Graham \& Berninger, 1998; Berninger \& Winn, 2006) eta baita euskaraz, gaztelaniaz eta ingelesez ere (Ibarra, 2016). Badirudi gakoa lan-oroimena dela: zenbat eta letrak automatizatuago egon, orduan eta baliabide gehiago du idazleak beste zeregin batzuetarako, goi-mailako testuak sortzeko adibidez. Ikuspuntu honetatik, letra-abiadurak, mugatutako denboran eginiko Kopia proben bidez eta Alfabetoaren probaren bidez ebaluatu dira. Funtsezkoa dirudi, beraz, letra kopuruak ikasmailaka zehaztea eta kritikoak izan daitezkeen 
abiadurak identifikatzea, garaiz esku hartzeko. Horrela egin zuten Medwell, Strand \& Wrayk (2007). Egile horiek esan zuten 7 urteko 186 ikaslerekin eginiko ikerketan Alfabetoaren proban minutuko 12 letra baino gutxiago idatzi zuten zenbait ikasle arriskuan zeudela: kalitate gutxiko idazlanak egiteko arriskuan hain zuzen ere. Gainera, 10-11 urteko 198 ikaslerekin eginiko beste ikerketa batean, Medwell, Strand \& Wrayk (2009) adierazi zuten proba berean minutuko 22 letra baino gutxiago idazten zuten 10-11 urteko ikasleek ere arrisku bera zutela. Bestalde, neurogarapeneko ikuspuntuan eginiko zenbait ikerketatan letra-jarioan genero-desberdintasunak aurkitu dira: mutilek esanguratsuki emaitza baxuagoak izan dituzte. Hori gertatu izan da, adibidez, Berninger \& Fulleren (1992), Jonesen (2004, Study1) eta Kim, Al Otaiba, Wanzek \& Gatlinen (2014) ikerketetan.

\section{Gure ikerketa}

Gure ikerketaren helburuak honako hauek izan dira: lehenengoa, ezagutzea Lehen Hezkuntzan zehar zein diren euskarazko letra-abiaduraren batezbestekoak ikasmailaka; bigarrena, analizatzea zein diren generoaren araberako ezberdintasunak; eta, hirugarrena, aztertzea generoaren eta ikasmailaren arteko elkarrekintza.

\subsection{Metodologia}

Gure ikerketako lagina 552 ikaslekoa da. Lehen Hezkuntzako 2., 4. eta 6. mailetako ikasleak dira. 2. mailan 214 ikasle dira (\% 38,8), 4. mailan 174 ikasle (\% 31,5) eta 6. mailan 164 ikasle (\% 29,7). Laginetik kanpo gelditu dira behar bereziak dituzten ikasleak (hizkuntza-atzerapena, laguntzailea dutenak...) eta soilik orain dela bi urtez geroztik bizi direnak EAEn. Adinari dagokionez, 7-13 urte bitarteko ikasleak dira; batez besteko adina 9,25 da eta desbiderapen tipikoa 1,769 da. Generoari dagokionez, neskak \% 47,4 dira eta mutilak \% 52,6. Lagin honetako ikasleak lau ikastetxetakoak dira, $\mathrm{D}$ eredukoak. Ikastetxeetako hiru itunpekoak dira eta bertan dago laginaren $\%$ 56. Ikastetxeetako bat publikoa da eta bertan dago laginaren \% 44. Ikasle gehienak Zarautzen (\% 68,6) eta Donostian (\% 21,9) bizi diren arren, \% 9,5 inguruko herrietan bizi da (Getaria, Astigarraga, Hernani, etab.). Prozedurari dagokionez, 2010. urteko martxoan eskola desberdinekin adostu ondoren, proba pilotuak egin ziren ikastetxe batean, Lehen Hezkuntzako 2. mailakoekin (28 ikasle) eta 4. mailakoekin (18 ikasle). Proba pilotuen ondoren, lagin guztiari pasatu zitzaizkion probak, 26 gelari hain zuzen ere. Artikulu honen egileetako bat aritu zen gela bakoitzean probak pasatzen eta gela bakoitzarekin 3,5 ordu eman genituen bi astetan zehar (bi ordu aste batean eta beste ordu eta erdi hurrengo astean). 


\subsection{Tresnak eta neurriak}

Gure laginean letren abiadura hiru modutan neurtu da: Alfabetoaren probaren bidez, Kopia lasaiaren probaren bidez eta Kopia azkarraren probaren bidez. Hiru probak sortu/moldatu egin ditugu ingelesezko proba batzuetatik.

Alfabetoaren probaren kontsignarako eta interpretaziorako eredutzat hartu dugun proba The Orthographic-Motor Integration (O.M.I.) (Jones, 2004) izan da. Eredutzat proba hori hartu izanaren arrazoi nagusia taldeka aplikatu izana da, izan ere, ohikoa izan da Alfabetoaren proba bakarka aplikatzea. Writing Speed and Accuracy Measure horren antzekoa sortuz, esku-idazketaren automatikotasunari buruzko informazioa jasotzea espero da. Honela, minutu batean buruz alfabetoa idaztea eskatu da, kontsigna hau delarik: «Idatz ezazu alfabetoa jarraian, AZKAR eta letra ULERGARRIAK eginez. Lehenengo letra txikiz egin. Bukatzen duzunean letra handiz egin». Proba honekin minutu batean, sekuentzia zuzenean eta modu ulergarrian egin den letra kopurua zenbatu da. Kontuan hartu dira bi gertaera: (1) Batzuetan soinuak idatzi dira (adibidez «be» idatzi da«b» idatzi beharrean). Kasu horietan «e» letra ere alfabetoko letra bat bezala zenbatu da. (2) Ikasle batzuek alfabetoa idatzi dutenean kontsonante bikoitzak idatzi dituzte, hau da, «rr», «ch», «ll» eta «RR» kontsonanteak; kasu hauetan kontsonante bikoitza letra bi balira bezala zenbatu da.

Kopia lasaiaren eta Kopia azkarraren probaren kontsignarako eta interpretaziorako eredutzat hartu ditugun probak DASH testeko Copy Best eta Copy Fast probak izan dira (Barnett et al., 2007). Euskaraz erabiliko dugun esaldiarekin zalantzak izan ditugu, izan ere, Copy Best eta Copy Fast proba hauetako ingelesezko esaldia «The quick brown fox jumps over the lazy dog» da. Esaldi horrek alfabetoko letra guztiak ditu eta oso erabilia izan da, test bihurtzeraino (Wallen et al. 1996). Bestalde, ingelesez sortu diren probetako askoren helburua haurrek hitzak edo esaldiak erraz gogoratzea zen, adibidez «Cat and dog» hitzak (Ziviani, 1984). Era berean, ordea, hain hitz gutxi idaztea kritikatua izan da (Rosenblum et al. 2003). Euskaraz zein esaldi erabili erabakitzen aritu ondoren, "Amaiak flan handia janda ospatu zuen bere eguna» esaldiaren aldeko apustua egin dugu. Batetik, erraz gogoratzeko esaldia izan daitekeelako; bestetik, "The quick brown fox jumps over the lazy dog» esaldiaren antzeko hitz kopurua duelako; eta, azkenik, kaligrafia arazo gutxi plantea ditzakeelako (hau da, ez du «tz» loturarik, «br» loturarik...). Gainera, alfabetoko letra guztiak egotearen baldintza ez da lehentasunezkoa izan, izan ere, laginean pasatuko dugun beste proba batean, Alfabetoaren proban, alfabetoko letra guztiak daude. Beraz, azkenean euskaraz 8 hitz edo 40 letra dituen esaldia asmatu da. Proba pasatu ostean, idatzi diren hitzak zenbatu dira, DASH testeko Copy Best eta Copy Fast proban agertzen diren irizpideei jarraituz (Barnett et al., 2007). Letra kopurua hitz kopurua baino neurri zehatzagoa dela jakinda ere (Graham et al., 1998) DASHeko irizpideei jarraitu diegu. 
Kopia lasaiaren probarako erabili den kontsigna hauxe izan da: «Idatz ezazu ondorengo esaldi hau behin eta berriro, AHALIK ETA LETRA HOBERENAREKIN: Amaiak flan handia janda ospatu zuen bere eguna». Ikasleei denboraren aipamenik egin gabe, 2 minutura arkatzak jasotzeko eskatu zaie. Proba horren bidez letrarik hoberena eginez eta presarik gabeko testuinguruan eginiko kopiari buruzko informazioa jaso nahi da, hau da, ikaslearen kopiatzeko ohiko erritmoa. Beraz, proba honetatik zera lortu dugu: 2 minututan kopiatu den hitz ulergarri kopurua letrarik hoberena eginez.

Kopia azkarraren probarako erabili den kontsigna hauxe izan da: «Idatz ezazu ondorengo esaldi hau behin eta berriro, AZKAR eta letra ULERGARRIAK eginez. Nik esan arte segi horrela: "Amaiak flan handia janda ospatu zuen bere eguna"». Bi minutuz kopiatzen utzi ondoren, hitzak zenbatu dira, Kopia lasaiaren proban bezala. Beraz, proba honetatik zera lortu dugu: 2 minututan azkar edo presarekin kopiatu den hitz kopurua.

\subsection{Emaitzak}

Ondoren aurkeztuko ditugu, batetik, euskarazko esku-idazketaren jarioaren hiru probetan Lehen Hezkuntzako 2., 4. eta 6. mailakoek agertzen dituzten desberdintasunak; bestetik, hiru proba horietako bakoitzean, ikasmaila bakoitzean, generoaren arabera dauden desberdintasunak eta, azkenik, ikasmailaren eta generoaren araberako bariantza-analisia. Grafikoen eta taulen bidez aurkeztuko dira honako emaitza hauek: batezbestekoak $(\overline{\mathrm{x}})$, desbiderapen tipikoak (D.T), F balioak eta batezbestekoen artean signifikazio-mailak (Sig.).

\section{Esku-idazketaren jarioaren hiru probetan}

Lehen Hezkuntzako 2., 4. eta 6. mailakoek dituzten desberdintasunak

ALFABETOAREN PROBAN MINUTU BATEAN IDATZI DEN LETRA KOPURUA

2., 4. ETA 6. MAILETAN

Ondoren, Alfabetoaren probaren bariantzaren analisiak aurkezten dira taula batean.

\section{1. taula}

Alfabetoaren probaren emaitzak 2., 4. eta 6. mailetan

\begin{tabular}{|c|c|c|c|c|c|}
\hline & $\begin{array}{l}\text { 2. maila } \\
\mathrm{n}=208\end{array}$ & $\begin{array}{l}\text { 4.maila } \\
\mathrm{n}=171\end{array}$ & $\begin{array}{l}\text { 6.maila } \\
\mathrm{n}=160\end{array}$ & \multirow[t]{2}{*}{ F } & \multirow[t]{2}{*}{ Sig. } \\
\hline & $\overline{\mathrm{x}}$ D.T & $\overline{\mathrm{x}} \quad$ D.T & $\overline{\mathrm{x}} \quad$ D.T & & \\
\hline Alfabetoaren proba (0-74) & $\begin{array}{l}13,99 \\
(6,78)\end{array}$ & $\begin{array}{c}31,16 \\
(12,58)\end{array}$ & $\begin{array}{c}43,63 \\
(11,34)\end{array}$ & 383,82 & 0,00 \\
\hline
\end{tabular}


Alfabetoaren proban minutu batean sekuentzian eta modu ulergarrian idatzi den alfabetoko letra kopurua ebaluatu da. Taulan ikusten denaren arabera, proba honetan, ikasmailaz ikasmaila alfabetoko letra kopurua handituz joan da; izan ere, 2. mailan batez beste minutuko 13,99 letra idatzi dituzte, 4. mailan 31,16 letra eta 6. mailan 43,63 letra. ANOVA egin ondoren, efektu nagusia esanguratsua dela ikusi da $(\mathrm{F}=383,82 \mathrm{p}=0,00)$. Gainera, Schefféren testaren analisia egin ondoren, hiru ikasmailen arteko desberdintasunak esanguratsuak direla ikusi da: 2 . mailaren eta 4 . mailaren arteko desberdintasunak esanguratsuak dira $(p=0,00), 4$. mailaren eta 6 . mailaren arteko desberdintasunak ere bai $(p=0,00)$ eta 2 . mailaren eta 6 . mailaren artekoak ere bai $(p=0,00)$. Aipatu beharra dago, baita ere, letra kopurua gehiago handitu dela 2. mailatik 4. mailara (bikoitza baino gehiago), 4. mailatik 6. mailara baino.

KOPIA LASAIAREN PROBAN BI MINUTUTAN KOPIATU DEN HITZ KOPURUA, 2., 4. ETA 6. MAILETAN

Ondoren, Kopia lasaiaren probaren bariantzaren analisiak aurkezten dira, hiru ikasmailatan.

\section{2. taula}

Kopia lasaiaren probaren emaitzak, 2., 4. eta 6. mailetan

\begin{tabular}{|c|c|c|c|c|c|}
\hline & $\begin{array}{l}\text { 2. maila } \\
\mathrm{n}=213\end{array}$ & $\begin{array}{l}\text { 4. maila } \\
\mathrm{n}=169\end{array}$ & $\begin{array}{l}\text { 6. maila } \\
\mathrm{n}=162\end{array}$ & \multirow[t]{2}{*}{$\mathrm{F}$} & \multirow{2}{*}{ Sig. } \\
\hline & $\overline{\mathrm{x}}$ D.T & $\overline{\mathrm{x}} \quad$ D.T & $\overline{\mathrm{x}} \quad$ D.T & & \\
\hline Kopia lasaiaren proba $(0-46)$ & $\begin{array}{c}7,26 \\
(3,38)\end{array}$ & $\begin{array}{l}15,31 \\
(6,35)\end{array}$ & $\begin{array}{l}20,62 \\
(7,10)\end{array}$ & 265,75 & 0,00 \\
\hline
\end{tabular}

2. taulan ikusten den moduan, Kopia lasaiaren proban, bi minutuz esaldi bat kopiatzeko eskatu da, letrarik hoberenarekin. Proba honetan bi minutuz idatzi diren hitzak zenbatu dira. Honela, ikasmailaz ikasmaila handituz joan da lasai kopiatu duten hitz kopurua, izan ere, 2. mailan bi minutu$\tan 7,26$ hitz kopiatu dituzte, 4. mailan 15,31 hitz eta 6. mailan 20,62 hitz. ANOVA egin ondoren, efektu nagusia esanguratsua dela ikusi da ( $F=265,75$ $\mathrm{p}=0,00)$. Gainera, Scheffé-ren testaren analisia egin ondoren, zera ikusi da: esanguratsuak dira 2. eta 4. mailen arteko desberdintasunak $(p=0,00)$, baita 2. eta 6. mailen artekoak ere $(p=0,00)$ eta baita 4 . eta 6 . mailen artekoak ere $(p=0,00)$. Proba honetan ere handiagoa da 2 . mailatik 4 . mailara arteko igoera 4. mailatik 6. mailara artekoa baino. 
KOPIA AZKARRAREN PROBAN BI MINUTUTAN AZKAR KOPIATU DEN HITZ KOPURUA

Ondoren, Kopia azkarraren probaren bariantzaren analisiak aurkezten dira, hiru ikasmailatan.

\section{3. taula}

Kopia azkarraren probaren emaitzak 2. , 4. eta 6. mailetan

\begin{tabular}{|c|c|c|c|c|c|}
\hline & $\begin{array}{l}\text { 2. maila } \\
\mathrm{n}=213\end{array}$ & $\begin{array}{l}\text { 4.maila } \\
\mathrm{n}=169\end{array}$ & $\begin{array}{l}\text { 6.maila } \\
\mathrm{n}=162\end{array}$ & \multirow[t]{2}{*}{$\mathrm{F}$} & \multirow[t]{2}{*}{ Sig. } \\
\hline & $\overline{\mathrm{x}} \quad$ D.T & $\overline{\mathrm{x}} \quad$ D.T & $\overline{\mathrm{x}} \quad$ D.T & & \\
\hline Kopia azkarraren proba $(0-47)$ & $\begin{array}{l}10,40 \\
(4,71)\end{array}$ & $\begin{array}{l}22,04 \\
(6,65)\end{array}$ & $\begin{array}{l}27,54 \\
(8,93)\end{array}$ & 314,80 & 0,00 \\
\hline
\end{tabular}

Kopia azkarraren proban, bi minutuz esaldi baten kopia azkarra egiteko eskatu da. Proba honetan bi minutuz azkar kopiatu diren hitzak zenbatu dira. Taulan ikusten denaren arabera, ikasmailaz ikasmaila handituz joan da azkar kopiatu duten hitz kopurua, izan ere, 2. mailan 10,40 hitz kopiatu dituzte, 4. mailan 22,04 hitz eta 6 . mailan 27,54 hitz. ANOVA egin ondoren, efektu nagusia esanguratsua dela ikusi da $(\mathrm{F}=314,80 \mathrm{p}=0,00)$. Gainera, Scheffé-ren testaren analisia egin ondoren, zera ikusi da: esanguratsuak dira 2. eta 4. mailen arteko desberdintasunak $(p=0,00)$, baita 2. eta 6. mailen artekoak $(p=0,00)$ ere, eta baita 4 . eta 6 . mailen artekoak ere $(p=0,00)$.

Ondoren erakusten ditugu, laburbilduta, grafiko batean, esku-idazketaren jarioaren hiru proben emaitzak hiru ikasmailetan zehar. Kontuan izan behar da grafikoa begiratzerakoan, kopiaren bi probetan bi minututan idatzitako hitzen batezbestekoak erakusten direla eta Alfabetoaren proban, aldiz, minutu batean idatzitako alfabetoko letrak.

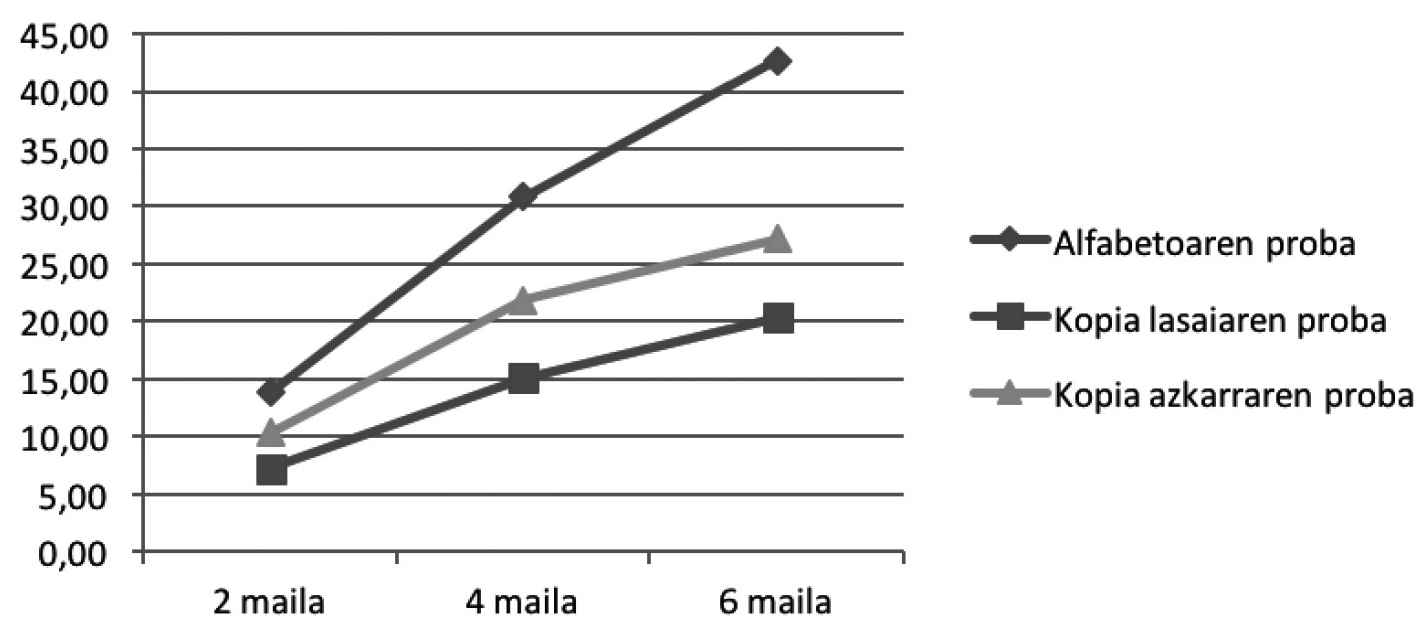

1. grafikoa

Lehen Hezkuntzako 2., 4. eta 6. mailetan letren/hitzen kopuruak 
Beraz, laburbilduz, hauxe baiezta daiteke:

- Esku-idazketaren jarioa esanguratsuki handiagoa da ikasmailaz ikasmaila; hau da, Alfabetoaren proban idatzi den letra kopurua eta Kopia lasaiaren eta Kopia azkarraren probetan kopiatu den hitz kopurua esanguratsuki handiagoa da 6. mailan 4. eta 2. mailetan baino; esanguratsuki handiagoa da halaber 4. mailan 2. mailan baino.

- 2. mailan batez beste minutuko sortu duten alfabetoko letra kopurua $13 \mathrm{da}$, bi minututan lasai kopiatu duten hitz kopurua 7 da eta bi minututan azkar kopiatu duten hitz kopurua 10 da.

- 4. mailan batez beste minutuko sortu duten alfabetoko letra kopurua 31 da, bi minututan lasai kopiatu duten hitz kopurua 15 da eta bi minututan azkar kopiatu duten hitz kopurua 22 da.

- 6. mailan batez beste minutuko sortu duten alfabetoko letra kopurua $43 \mathrm{da}$, bi minututan lasai kopiatu duten hitz kopurua 20 da eta bi minututan azkar kopiatu duten hitz kopurua 27 da.

Esku-idazketaren jarioan ikasmaila bakoitzean generoaren arabera dauden desberdintasunak

Ondoren aurkezten dira generoaren arabera esku-idazketaren jarioan egon diren aldeak maila desberdinetan, hau da, 2., 4. eta 6. mailetan, grafikoaren bidez eta taularen bidez.

\section{BIGARREN MAILAKO EMAITZAK}

Hona hemen 2. mailako emaitzak, grafikoaren bidez eta taularen bidez.

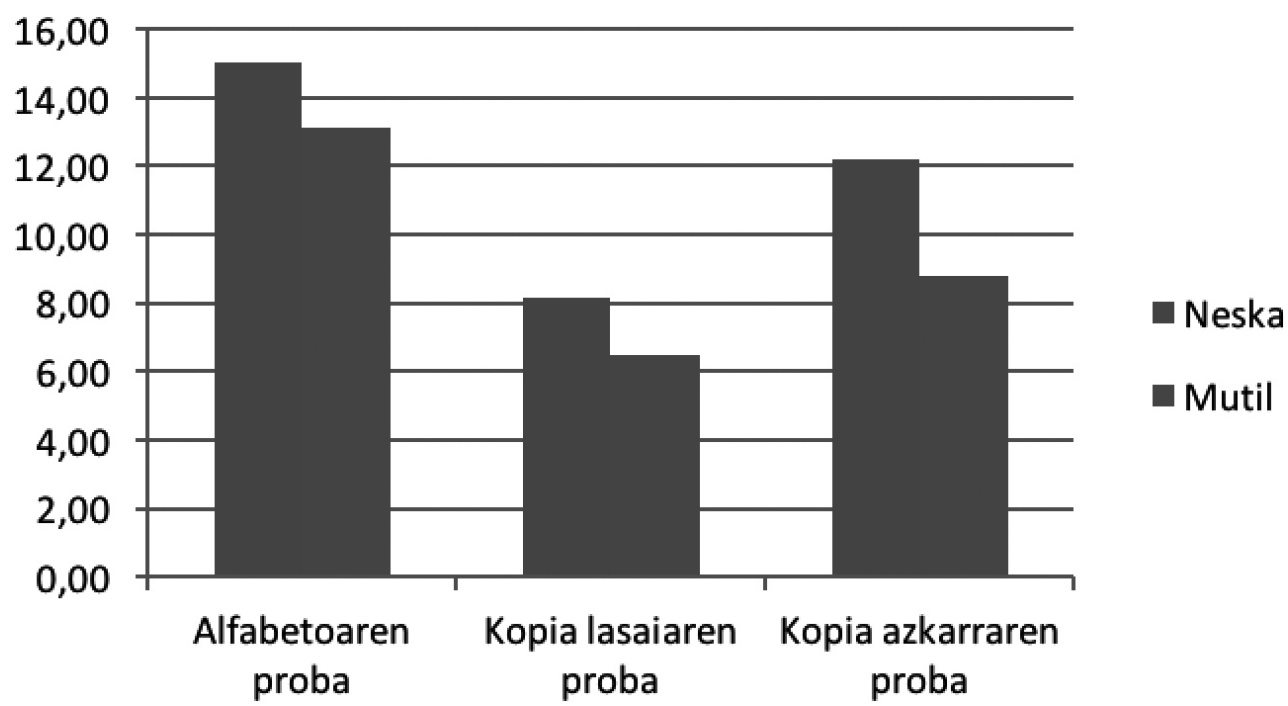

2. grafikoa

Generoaren araberako esku-idazketaren jarioa, 2. mailan 


\section{4. taula}

Generoaren araberako esku-idazketaren jarioa, 2. mailan

\begin{tabular}{|c|c|c|c|c|c|}
\hline \multirow[t]{2}{*}{ Esku-idazketaren jarioa } & $\begin{array}{c}\text { Neska } \\
(101)\end{array}$ & $\begin{array}{c}\text { Mutila } \\
\text { (113) }\end{array}$ & \multirow[t]{2}{*}{$t$} & \multirow[t]{2}{*}{ Sig. } & \multirow[t]{2}{*}{ Hedges $\mathrm{g}$} \\
\hline & $\overline{\mathrm{x}} \quad$ D.T & $\overline{\mathrm{x}}$ D.T & & & \\
\hline Alfabetoaren proba (0-37) & $\begin{array}{l}15,01 \\
(7,33)\end{array}$ & $\begin{array}{l}13,10 \\
(6,16)\end{array}$ & 2,04 & 0,04 & 0,2824 \\
\hline Kopia lasaiaren proba $(0-17)$ & $\begin{array}{c}8,14 \\
(3,32)\end{array}$ & $\begin{array}{c}6,49 \\
(3,26)\end{array}$ & 3,65 & $<0,000$ & 0,4920 \\
\hline Kopia azkarraren proba (0-25) & $\begin{array}{l}12,17 \\
(4,71)\end{array}$ & $\begin{array}{c}8,81 \\
(4,11)\end{array}$ & 5,54 & $<0,000$ & 0,7603 \\
\hline
\end{tabular}

Emaitzek erakusten dutenez, 2. mailan neskek mutilek baino esanguratsuki emaitza hobeak izan dituzte esku-idazketaren jarioaren hiru probe$\tan$, hau da, Alfabetoaren proban $(t=2,04 \mathrm{p}=0,04)$, Kopia lasaiaren proban $(\mathrm{t}=3,65 \mathrm{p}=<0,000)$ eta Kopia azkarraren proban $(\mathrm{t}=5,54 \mathrm{p}=<0,000)$. Beraz, neskek alfabetoko letra esanguratsuki gehiago sortu dute minutu batean eta hitz gehiago kopiatu dute presarik gabe eta azkar, bi minututan. Gainera, desberdintasunik handienak Kopia azkarraren proban izan dira $(t=5,54)$.

\section{LAUGARREN MAILAKO EMAITZAK}

Hona hemen laugarren mailako emaitzak, grafikoaren bidez eta taularen bidez.

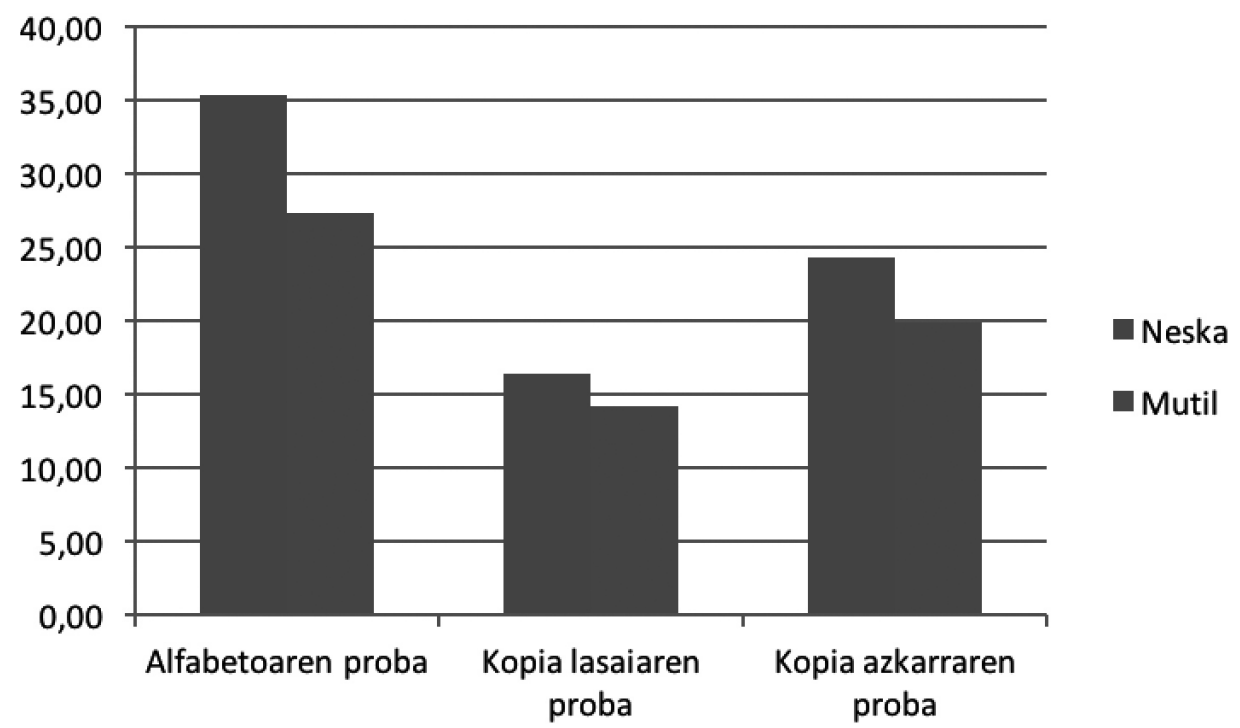

3. grafikoa

Generoaren araberako esku-idazketaren jarioa, 4. mailan 


\section{5. taula}

Generoaren araberako esku-idazketaren jarioa, 4. mailan

\begin{tabular}{|c|c|c|c|c|c|}
\hline \multirow{2}{*}{ Esku-idazketaren jarioa } & $\begin{array}{l}\text { Neska } \\
(83)\end{array}$ & $\begin{array}{l}\text { Mutila } \\
(90)\end{array}$ & \multirow{2}{*}{$\mathrm{t}$} & \multirow{2}{*}{ Sig. } & \multirow{2}{*}{$\begin{array}{c}\text { Hedges } \\
\text { g }\end{array}$} \\
\hline & $\overline{\mathrm{x}}$ D.T & $\overline{\mathrm{x}}$ D.T & & & \\
\hline Alfabetoaren proba (letrak 0-67) & $\begin{array}{c}35,33 \\
(12,20)\end{array}$ & $\begin{array}{c}27,31 \\
(11,74)\end{array}$ & 4,33 & $<0,000$ & 0,6674 \\
\hline Kopia lasaiaren proba (hitzak 1-40) & $\begin{array}{l}16,43 \\
(6,17)\end{array}$ & $\begin{array}{l}14,25 \\
(6,36)\end{array}$ & 2,39 & 0,02 & 0,3461 \\
\hline Kopia azkarraren proba (hitzak 3-44) & $\begin{array}{l}24,28 \\
(6,09)\end{array}$ & $\begin{array}{l}19,92 \\
(6,49)\end{array}$ & 4,51 & $<0,000$ & 0,6888 \\
\hline
\end{tabular}

Taulan ikusten denez, 4. mailan neskek mutilek baino esanguratsuki emaitza hobeak izan dituzte esku-idazketaren jarioaren hiru probetan, hau da, Alfabetoaren proban $(\mathrm{t}=4,33 \mathrm{p}=<0,000)$, Kopia lasaiaren proban $(\mathrm{t}=2,39 \mathrm{p}=0,02)$ eta Kopia azkarraren proban $(\mathrm{t}=4,51 \mathrm{p}=<0,000)$. Beraz, 4. mailan esanguratsuki handiagoak dira nesken eta mutilen arteko aldeak. Desberdintasunik handienak Alfabetoaren proban eta Kopia azkarraren proban izan dira (hurrenez hurren $t=4,33$ eta $t=4,51$ ).

SEIGARREN MAILAKO EMAITZAK

Hona hemen seigarren mailako emaitzak grafikoan eta taulan.

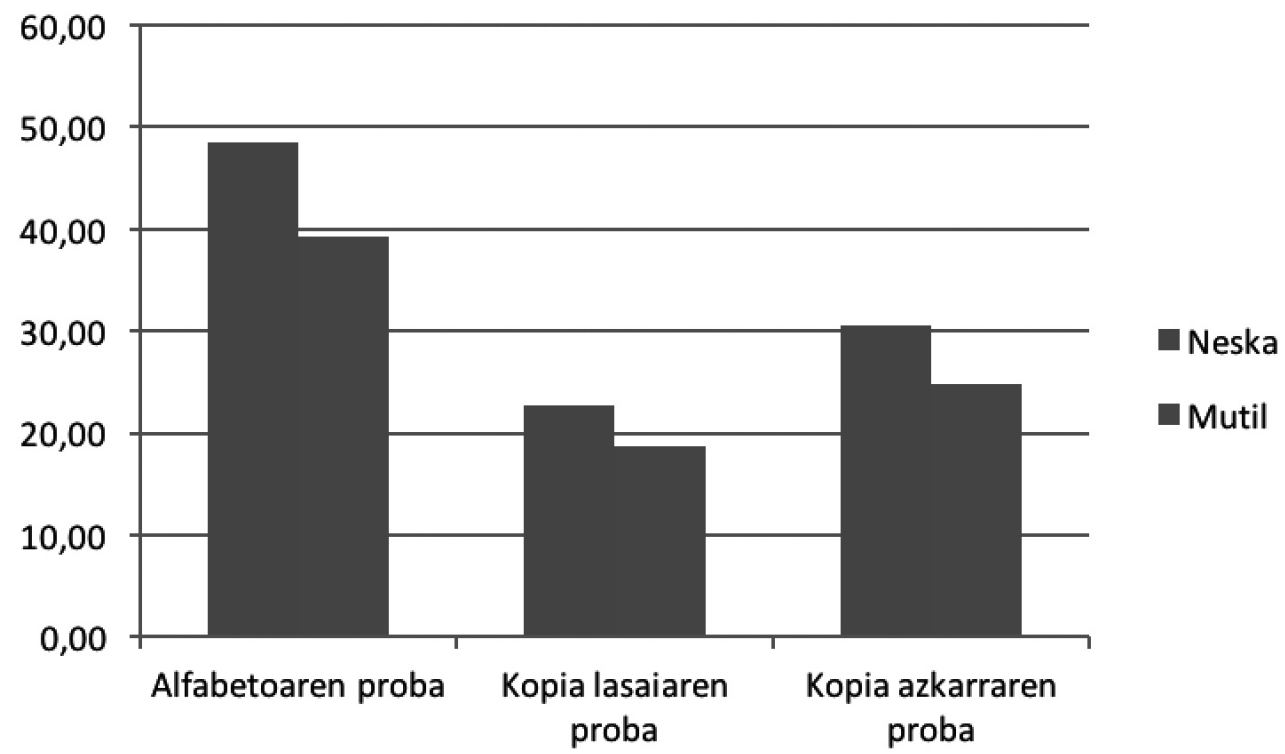

4. grafikoa

Generoaren araberako esku-idazketaren jarioa, 6. mailan 
6. taula

Generoaren araberako esku-idazketaren jarioa, 6. mailan

\begin{tabular}{|c|c|c|c|c|c|}
\hline \multirow{2}{*}{ Esku-idazketaren jarioa } & $\begin{array}{l}\text { Neska } \\
(76)\end{array}$ & $\begin{array}{c}\text { Mutila } \\
(87)\end{array}$ & \multirow[t]{2}{*}{$\mathrm{t}$} & \multirow{2}{*}{ Sig. } & \multirow{2}{*}{$\begin{array}{c}\text { Hedges } \\
\mathrm{g}\end{array}$} \\
\hline & $\overline{\mathrm{x}} \quad$ D.T & $\overline{\mathrm{x}} \quad$ D.T & & & \\
\hline Alfabetoaren proba (15-74) & $\begin{array}{c}48,43 \\
(10,19)\end{array}$ & $\begin{array}{c}39,29 \\
(10,59)\end{array}$ & 5,61 & $<0,000$ & 0,8742 \\
\hline Kopia lasaiaren proba (0-17) & $\begin{array}{l}22,71 \\
(6,21)\end{array}$ & $\begin{array}{l}18,67 \\
(7,33)\end{array}$ & 3,75 & $<0,000$ & 0,5886 \\
\hline Kopia azkarraren proba (3-44) & $\begin{array}{l}30,51 \\
(6,84)\end{array}$ & $\begin{array}{l}24,84 \\
(9,78)\end{array}$ & 4,22 & $<0,000$ & 0,6610 \\
\hline
\end{tabular}

6. taulan ikusten denaren arabera, 6. mailan neskek mutilek baino esanguratsuki emaitza hobeak izan dituzte esku-idazketaren jarioan, hau da, Alfabetoaren proban $(\mathrm{t}=5,61 \mathrm{p}=<0,000)$, Kopia lasaiaren proban $(\mathrm{t}=3,75$ $\mathrm{p}=<0,000)$ eta Kopia azkarraren proban $(\mathrm{t}=4,22 \mathrm{p}=<0,000)$. Beraz, alde esanguratsuak daude nesken alde Alfabetoaren proban, Kopia lasaiaren proban eta Kopia azkarraren proban. Desberdintasunik handienak Alfabetoaren proban izan dira $(t=5,61)$.

Generoaren faktorearen eragina laburbilduz, hauxe aurkitu da: 2., 4. eta 6. mailetan esku-idazketaren jarioaren hiru probetan neskek esanguratsuki emaitza hobeak izan dituzte mutilen aldean; hau da, Alfabetoaren proban, Kopia lasaiaren proban eta Kopia azkarraren proban neskek mutilek baino esanguratsuki letra eta hitz gehiago idatzi eta kopiatu dute. Gainera, Alfabetoaren proban desberdintasunak are eta nabarmenagoak dira.

\section{Ikasmailaren eta generoaren araberako bariantza-analisia}

Ikerketa bukatzeko, generoaren eta ikasmailaren arteko elkarrekintza analizatu dugu; horretarako, bi osagaien arteko bariantzaren analisia egin dugu eta emaitzak hauexek izan dira hiru probetan, hau da, Alfabetoaren proban, Kopia azkarraren proban eta Kopia lasaiaren proban.

\section{AlFABETOAREN PROBA}

Alfabetoaren proban, ondorengo taulan ikus daitekeenez, ANOVAren emaitzaren arabera, bi aldagai independenteen elkarrekintzak (generoa eta ikasmaila) 0.028ko esanguratasun-maila du; eta, ikerketa deskribatzailearekin batera, badirudi neska-mutilen arteko desberdintasunak handituz doazela ikasmailetan gora egin ahala. Ikusi 7. taula eta berari dagokion 1. irudia. 


\section{7. taula}

Subjektu-arteko efektuen probak. Menpeko aldagaia: Alfabetoaren proba

\begin{tabular}{lcrrrrr}
\hline & \multicolumn{7}{c}{ Alfabetoaren proba } \\
\cline { 2 - 7 } \multicolumn{1}{c}{ Iturria } & $\begin{array}{c}\text { III. mota } \\
\text { karratuen } \\
\text { batura }\end{array}$ & A.g. & $\begin{array}{c}\text { Batezbesteko } \\
\text { kuadratikoa }\end{array}$ & F & Sig. & $\begin{array}{c}\text { Eta } \\
\text { karratua }\end{array}$ \\
\hline Zuzendutako eredua & $86984,752^{\text {a }}$ & 5 & 17396,950 & 182,694 &, 000 &, 632 \\
Intersekzioa & 467371,395 & 1 & 467371,395 & 4908,091 &, 000 &, 902 \\
Mailak & 81789,394 & 2 & 40894,697 & 429,455 &, 000 &, 618 \\
Generoa & 5390,215 & 1 & 5390,215 & 56,605 &, 000 &, 096 \\
Mailak * Generoa & 1454,109 & 2 & 727,054 & 7,635 &, 001 &, 028 \\
Errorea & 50659,525 & 532 & 95,225 & & & \\
\hline Totala & 564435,000 & 538 & & & & \\
\hline Zuzendutako totala & 137644,277 & 537 & & & & \\
\hline
\end{tabular}

$\mathrm{R}$ karratua $=, 632(\mathrm{R}$ karratu zuzendua $=, 628)$.

Behin betiko Alfabeto aldagaiaren batezbesteko marjinalak

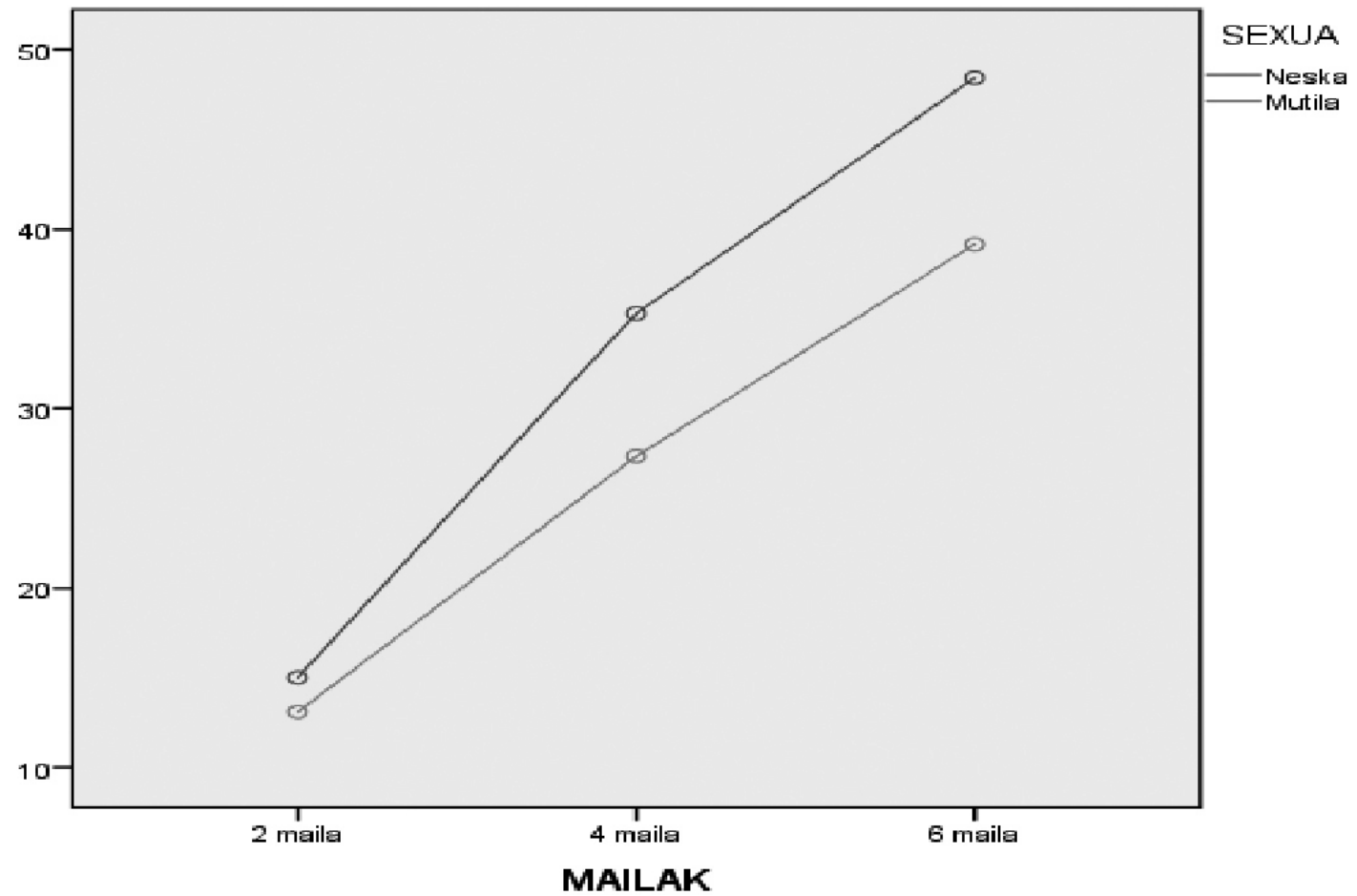

1. irudia

Alfabetoaren probaren emaitzak, generoaren eta mailaren arabera 
Efektuaren tamainaren adierazle gisan, Eta karratu zuzenduaren balioa 0.628koa dela esan dezakegu. Taulan agertzen diren ANOVAren emaitzen arabera, ikasmaila guztietan nesken batezbestekoa mutilena baino handiagoa da. Alfabetoaren proban generoaren arabera dauden desberdintasunak handitu egiten dira ikasmailetan gora egin ahala. Eta, logikoa den bezala, proba honetako emaitzen maila ere handitzen doa. Generoaren eta ikasmailaren arteko elkarrekintza esanguratsua da $(\operatorname{sig}=0,001)$.

\section{KOPIA LASAIAREN PROBA}

Kopia lasaiaren proban, ondorengo taulan ikus daitekeenez, ANOVAren emaitzaren arabera, bi aldagai independenteen elkarrekintzak (generoa eta ikasmaila) 0.008ko esanguratasun-maila du; eta, ikerketa deskribatzailearekin batera, badirudi neska-mutilen arteko desberdintasunak handituz doazela ikasmailetan gora egin ahala. Ikusi 8. taula eta berari dagokion 2. irudia.

\section{8. taula}

Subjektu-arteko efektuen probak.

Menpeko aldagaia: Kopia lasaiaren proba

\begin{tabular}{lcrrrrr}
\hline \multirow{2}{*}{ Iturria } & \multicolumn{7}{c}{ Kopia lasaiaren proba } \\
\cline { 2 - 7 } & $\begin{array}{c}\text { III. mota } \\
\text { karratuen } \\
\text { batura }\end{array}$ & A.g. & $\begin{array}{c}\text { Batezbesteko } \\
\text { kuadratikoa }\end{array}$ & F & Sig. & $\begin{array}{c}\text { Eta } \\
\text { karratua }\end{array}$ \\
\hline Zuzendutako eredua & $17918,142^{\text {a }}$ & 5 & 3583,628 & 118,617 &, 000 &, 525 \\
Intersekzioa & 111444,891 & 1 & 111444,891 & 3688,805 &, 000 &, 873 \\
Mailak & 16968,041 & 2 & 8484,020 & 280,819 &, 000 &, 512 \\
Generoa & 948,390 & 1 & 948,390 & 31,392 &, 000 &, 055 \\
Mailak * Generoa & 135,671 & 2 & 67,835 & 2,245 &, 107 &, 008 \\
Errorea & 16193,444 & 536 & 30,212 & & & \\
\hline Totala & 136240,000 & 542 & & & & \\
\hline Zuzendutako totala & 34111,587 & 541 & & & \\
\hline
\end{tabular}

$\mathrm{R}$ karratua $=, 525$ (R karratu zuzendua $=, 521)$. 
Behin betiko Kopia lasaiaren aldagaiaren batezbesteko marjinalak

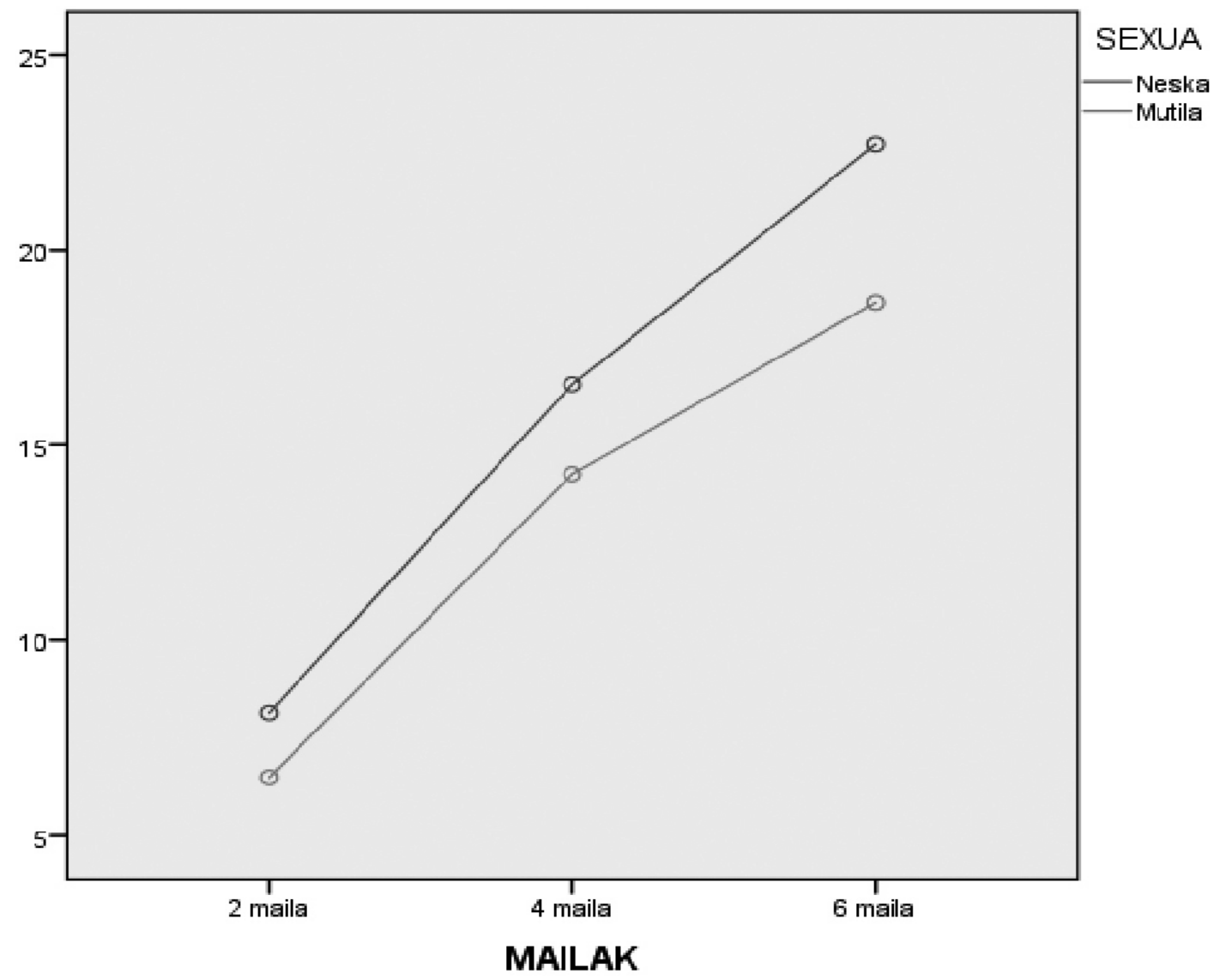

2. irudia

Kopia lasaiaren probaren emaitzak, generoaren eta mailaren arabera

Efektuaren tamainaren adierazle gisan, Eta karratu zuzenduaren balioa 0.521ekoa dela esan dezakegu. Taulan agertzen diren ANOVAren emaitzen arabera, ikasmaila guztietan nesken batezbestekoa mutilena baino handiagoa da. Kopia lasaiaren proban generoaren arabera dauden desberdintasunak handitu egiten dira ikasmailetan gora egin ahala. Eta, logikoa den bezala, proba honetako emaitzen maila ere handitzen doa. Baina generoaren eta ikasmailaren arteko elkarrekintza ez da esanguratsua (Sig.: 0,107) eta ikus daitekeenez bi lerroak ia paraleloak dira.

\section{KOPIA AZKARRAREN PROBA}

Kopia azkarraren proban, ondorengo taulan ikus daitekeenez, ANOVAren emaitzaren arabera, bi aldagai independenteen elkarrekintzak (generoa eta ikasmaila) 0.006ko esanguratasun-maila du; eta, ikerketa deskribatzailea- 
rekin batera, badirudi neska-mutilen arteko desberdintasunak handituz doazela ikasmailetan gora egin ahala. Ikusi 9. taula eta berari dagokion 3. irudia.

\section{9. taula}

Subjektu-arteko efektuen probak. Menpeko aldagaia: Kopia azkarraren proba

\begin{tabular}{lcrrrrr}
\hline \multirow{2}{*}{\multicolumn{1}{c}{ Iturria }} & \multicolumn{7}{c}{ Kopia azkarraren proba } \\
\cline { 2 - 7 } & $\begin{array}{c}\text { III. mota } \\
\text { katratuen }\end{array}$ & A.g. & $\begin{array}{c}\text { Batezbesteko } \\
\text { kuadratikoa }\end{array}$ & F & Sig. & $\begin{array}{c}\text { Eta } \\
\text { karratua }\end{array}$ \\
\hline Zuzendutako eredua & $31622,457^{\mathrm{a}}$ & 5 & 6324,491 & 150,942 &, 000 &, 585 \\
Intersekzioa & 214902,801 & 1 & 214902,801 & 5128,930 &, 000 &, 905 \\
Mailak & 29007,053 & 2 & 14503,527 & 346,145 &, 000 &, 564 \\
Generoa & 2689,210 & 1 & 2689,210 & 64,181 &, 000 &, 107 \\
Mailak * Generoa & 128,303 & 2 & 64,151 & 1,531 &, 217 &, 006 \\
Errorea & 22458,467 & 536 & 41,900 & & & \\
\hline Totala & 251533,000 & 542 & & & & \\
\hline Zuzendutako totala & 54080,924 & 541 & & & & \\
\hline
\end{tabular}

$\mathrm{R}$ karratua $=, 585(\mathrm{R}$ karratu zuzendua $=, 581)$.

Behin betiko Kopia azkarraren aldagaiaren batezbesteko marjinalak

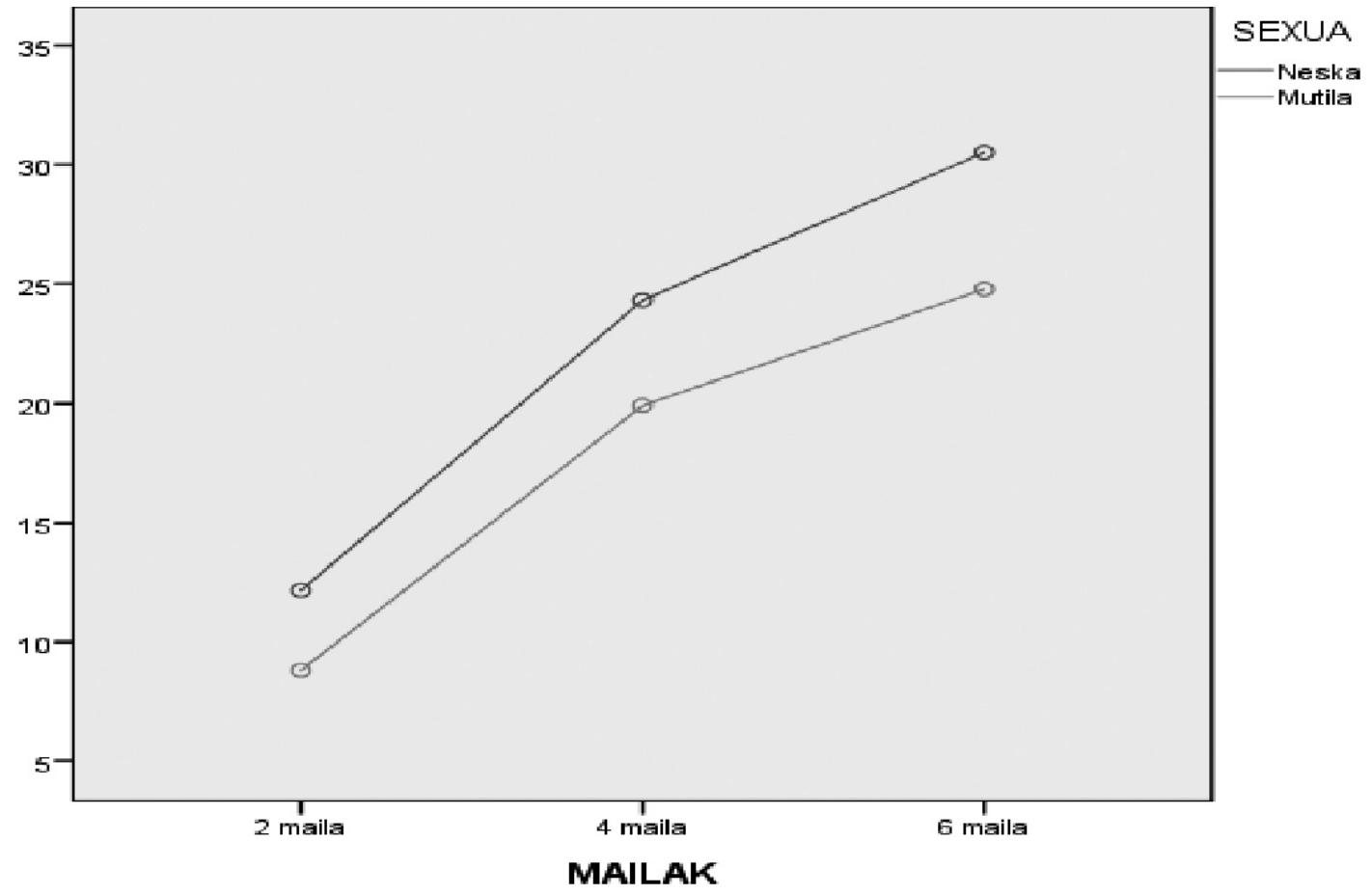

3. irudia

Kopia azkarraren probaren emaitzak, generoaren eta mailaren arabera 
Efektuaren tamainaren adierazle gisan, Eta karratu zuzenduaren balioa 0.581ekoa dela esan dezakegu. Taulan agertzen diren ANOVAren emaitzen arabera, ikasmaila guztietan nesken batezbestekoa mutilena baino handiagoa da. Kopia azkarraren proban generoaren arabera dauden desberdintasunak handitu egiten dira ikasmailetan gora egin ahala. Eta, beste probetan bezala, proba honetako emaitzen maila ere handitzen doa. Halere, generoaren eta ikasmailaren arteko elkarrekintza ez da esanguratsua (Sig.: 0,217) eta ikus daitekeenez bi lerroak ia paraleloak dira.

Laburbilduz, generoaren eta ikasmailaren arteko elkarrekintza aztertzeko bi osagaien arteko bariantzaren analisia egin dugu; eta, ikusi dugunez, soilik Alfabetoaren proban izan da esanguratsua bi osagaien arteko elkarrekintza.

\subsection{Konklusioak}

-Ikasmailaren arabera, esan dezakegu letra/hitz kopurua esanguratsuki handituz joan dela ikasmailaka gure laginean. Emaitza hori nazioartean aurkiturikoaren ildo berean doa (Berninger \& Fuller, 1992; Graham et al., 1998; O'Mahony et al., 2008; Barnett et al. 2009; Mackenzie et al., 2013). Gainera, letra kopurua askoz gehiago handitu da 2. mailatik 4. mailara (bikoitza baino gehiago), 4. mailatik 6. mailara baino. Beraz, emaitza horrek bat egiten du Graham et al.(1998)rekin.

-Azken batean, gure lagineko 2. mailako ikasleek batez beste minutuko sortu duten alfabetoko letra kopurua $13 \mathrm{da}$, bi minututan lasai kopiatu duten hitz kopurua 7 da eta bi minututan azkar kopiatu duten hitz kopurua 10 da. Gure lagineko 4. mailako ikasleek batez beste bi minutuko sortu duten alfabetoko letra kopurua 31 da, bi minututan lasai kopiatu duten hitz kopurua 15 da eta bi minututan azkar kopiatu duten hitz kopurua 22 da. Gure lagineko 6. mailako ikasleek batez beste minutuko sortu duten alfabetoko letra kopurua 43 da, bi minututan lasai kopiatu duten hitz kopurua 20 da eta bi minututan azkar kopiatu duten hitz kopurua 27 da (ikus 10. taula).

\section{0. taula}

2., 4. eta 6. mailako ikasleek esku-idazketaren jarioan izandako batezbestekoak

\begin{tabular}{lccc}
\hline & $\begin{array}{c}\text { Alfabetoaren proba } \\
\text { (letrak) }\end{array}$ & $\begin{array}{c}\text { Kopia lasaiaren } \\
\text { proba (hitzak) }\end{array}$ & $\begin{array}{c}\text { Kopia azkarraren } \\
\text { proba (hitzak) }\end{array}$ \\
\hline 2. maila & 13 & 7 & 10 \\
4. maila & 31 & 15 & 22 \\
6. maila & 43 & 20 & 27 \\
\hline
\end{tabular}


-Generoari dagokionez, lagin osoan generoaren araberako desberdintasun esanguratsuak aurkitu ditugu: neskek mutilek baino emaitza esanguratsuki hobeak lortu dituzte esku-idazketaren jarioan, hau da, Alfabetoaren proban, Kopia azkarrean eta Kopia lasaian. Hortaz, bat egiten dugu nazioartean aurkitutakoarekin, hala nola, Berninger \& Fuller (1992)rekin, Jones (2004, Study1)ekin eta Kim et al. (2014)rekin. Genero-asimetria esanguratsu horren arrazoiak desberdintasun neurologikoetan aurkitzen dituzte Berninger \& Fullerek (1992). Horien arabera, neskek ezkerreko hemisferioaren bidez kodetuko lituzkete letrak eta mutilek eskuineko hemisferioaren bidez, espazialki. Azken kodetze mota horrek letrak gogoratzea eta, ondorioz, idaztea geldiagotu egingo luke. Hala ere, oraindik ikerketa gehiago behar da arrazoiak aurkitzeko. Graham et al.-ek (1998) faktore biologikoak eta ingurunekoak aipatzen dituzte. Neskek motrizitate fina garatuagoa dutela agertzen duten ikerketa ugariak aipatzen dituzte eta baita ere, agian, estereotipo kulturalek esku-idazketaren garapenean eragiten dutela; izan ere, tradizionalki onartua egon da neskak mutilak baino esku-idazle hobeak direla.

Hitz gutxitan, hauexek dira gure laginean proba bakoitzean neskek eta mutilek lortu dituzten emaitzak ikasmailaka (ikus 11. taula).

\section{1. taula}

2., 4. eta 6. mailako ikasleek generoaren arabera esku-idazketaren jarioan izandako batezbestekoak

\begin{tabular}{lccc}
\hline & $\begin{array}{c}\text { Alfabetoaren proba } \\
\text { (letrak minutuko) } \\
\text { (neskak/mutilak) }\end{array}$ & $\begin{array}{c}\text { Kopia lasaiaren proba } \\
\text { (hitzak bi minutuko) } \\
\text { (neskak/mutilak) }\end{array}$ & $\begin{array}{c}\text { Kopia azkarraren } \\
\text { proba (hitzak bi } \\
\text { minutuko) (neskak/ } \\
\text { mutilak) }\end{array}$ \\
\hline 2. maila & $15 / 13$ & $8 / 6$ & $12 / 8$ \\
4. maila & $35 / 27$ & $16 / 14$ & $24 / 19$ \\
6. maila & $48 / 39$ & $22 / 18$ & $30 / 24$ \\
\hline
\end{tabular}

—Generoaren eta ikasmailaren arteko elkarrekintza aztertzeko bi osagaien arteko bariantzaren analisia egin dugularik ikusi dugu soilik Alfabetoaren proban izan dela esanguratsua bi osagaien arteko elkarrekintza.

Beraz, laburbilduz, artikulu honen bidez letren abiadura ebaluatzearen garrantzia nabarmendu da eta euskarazko batez besteko kopuruak agertu dira ikasmailaren eta generoaren arabera. Horrela, ikusi dugu, nazioarteko emaitzen ildo berean doazela gure datuak: letra-jario baxuetan eta mutiletan arreta berezia jarri beharko litzateke, esku-hartze goiztiarrak egiteko. Beraz, lanean jarraituko dugu euskaraz ere ebaluazio-test bat izan dezagun, eta oinarritzat Erresuma Batuko DASH testa hartuko dugu. 


\section{Erreferentzia bibliografikoak}

Amundson, Susan \& Marsha Weil (1996), «Prewriting and handwriting skills». In J. Case-Smith, A. Allen \& P. Pratt (arg.), Occupational therapy for children. Third edition. Chicago: Mosby, 524-541 or.

Barnett, Anna, Sheila Henderson, Beverly Scheib \& Joerg Schulz (2007), The Detailed Assessment of Speed of Handwriting. London: Harcourt Assessment.

Barnett, Anna, Sheila Henderson, Beverly Scheib \& Joerg Schulz (2009), «Development and standardisation of a new handwriting speed test: The DASH». British Journal of Educational Psychology Monograph Series 2: 137-157.

Berninger, Virginia (2007), Process assessment of the learner. Diagnostic for reading and writing (PAL-II RW). Second edition. San Antonio, TX: The Psychological Corporation.

Berninger, Virginia \& Frances Fuller (1992), «Gender differences in ortographic, verbal, and compositional fluency: Implications for diagnosis of writing disabilities in primary grade children». Journal of School Psychology 30: 363-382.

Berninger, Virginia \& Steve Graham (1998), «Language by hand: A synthesis of a decade of research on handwriting». Handwriting Review 12: 11-25.

Berninger, Virginia, Donald Mizokawa \& Russell Bragg (1991), «Theory-based diagnosis and remediation of writing disabilities». Journal of School Psychology 29: 57-97.

Berninger, Virginia \& Lee Swanson (1994), «Modifying Hayes and Flower's model of skilled writing to explain beginning and developing writing». In E. Butterfield (arg.) (2007. urtean berrargitaratua), Children's writing: Toward a process theory of the development of skilled writing. Greenwich, CT: JAI Press, 57-81 or.

Berninger, Virginia \& William Winn (2006), «Implications of advancements in brain research and technology for writing development, writing instruction, and educational evolution». In C. MacArthur, S. Graham \& J. Fitzgerald (arg.), The handbook of writing research. New York: Guilford, 96-114 or.

Graham, Steve, Virginia Berninger, Naomi Weintraub \& William Schafer (1998), «Development of handwriting speed and legibility». Journal of Educational Research 92: 42-51.

Haranburu, Mikel, Itziar Alonso-Arbiol, Nekane Balluerka \& Arantxa Gorostiaga (2008), Hizkuntza idatziaren didaktika Haur Hezkuntzan eta Lehen Hezkuntzan. Bilbo: Udako Euskal Unibertsitatea.

Ibarra, Irune (2016), Esku-idazketa eta testu eleanitzen arteko loturak. Doktoretza-tesia, Euskal Herriko Unibertsitatea.

Joint Council for Qualifications JCQ (2015), «Access arrangements and reasonable adjustments 2015-2016». Sarean: http://www.jcq.org.uk/exams-office/accessarrangements-and-special-consideration

Jones, Dian (2004), Automaticity of the transcription process in the production of written text. Doktoretza-tesia, University of Queensland.

Judd, Debra, James Siders, Jane Siders \& Kathleen Atkins (1986), «Sex-related differences on fine-motor tasks at grade one». Perceptual and Motor Skills 62: 307-312.

Kim, Young-Suk, Stephanie Al Otaiba, Jeanne Wanzek \& Brandy Gatlin (2014), «Towards an understanding of dimensions, predictors, and gender gap in written composition». Journal of Educational Psychology 107: 79-95.

Levin, Tarynn Ann (2010), The effect of assistive devices on writing speed and legibility in grade two learning disabled children. Doktoretza-tesia. Johannesburg: University of the Witwatersrand. 
Mackenzie, Noella, Janet Scull \& Lynne Munsie (2013), «Analysing writing: The development of a tool for use in the early years of schooling». Issues in Educational Research 23: 375-393.

Medwell, Jane, Steve Strand \& David Wray (2007), «The role of handwriting in composing for Y2 children». Journal of Reading, Writing and Literacy 2: 18-36.

Medwell, Jane, Steve Strand \& David Wray (2009), «The links between handwriting and composing for Y6 children». Cambridge Journal of Education 39: 329-344.

Medwell, Jane \& David Wray (2008), «Handwriting: a forgotten language skill? Language and Education 22: 34-47.

National Center for Education Statistics (2012), «The nation's report card: Writing 2011 (NCES 2012-470)». Institute of Education Sciences, U.S. Department of Education, Washington, D.C. Sarean: http://nces.ed.gov/nationsreportcard/pdf/ main2011/2012470.pdf)

O'Mahony, Paul, Mairead Dempsey \& Hazel Killeen (2008), «Handwriting Speed: duration of testing period and relation to socio-economic disadvantage and handedness». Occupational Therapy International 15: 165-77.

Overvelde, Anneloes \& Wouter Husltijn (2011), «Handwriting development in grade 2 and grade 3 primary school children with normal, at risk, or dysgraphic characteristics». Research in Developmental Disabilities 32: 540-548.

Rosenblum, Sara, Patrice Weiss \& Shula Parush (2003), «Product and process evaluation of handwriting difficulties: A review». Educational Psychology Review 15: 4181.

Wallen, Margaret, Mary-Ann Bonney \& Lyn Lennox (1996), The Handwriting Speed Test. Sydney, Australia: Occupational Therapy Australia.

Weintraub, Naomi \& Steve Graham (2000), «The contribution of gender, orthographic, finger function, and visual-motor processes to the prediction of handwriting status». Occupational Therapy Journal of Research 20: 121-140.

Ziviani, Jenny (1984), "Some elaborations on handwriting speed in 7- to 14-yearolds». Perceptual and Motor Skills 58: 535-539.

Ziviani, Jenny \& Amanda Watson-Will (1998), «Writing speed and legibility of 7-14-year-old school students using modern cursive script». Australian Occupational Therapy Journal 45: 59-64. 